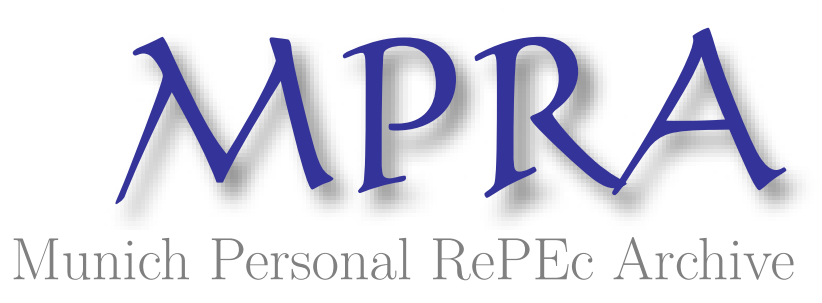

\title{
The political Economy of WTO with special reference to NAMA Negotiations
}

Shafaeddin, Mehdi

personal

September 2008

Online at https://mpra.ub.uni-muenchen.de/10894/

MPRA Paper No. 10894, posted 07 Oct 2008 02:38 UTC 


\title{
The political Economy of WTO \\ with special reference to NAMA Negotiations
}

\author{
Mehdi Shafaeddin* \\ Paper prepare for presentation at: \\ The Conference on Political Economy of International Organizations, \\ Geneva; January 29-31 2009
}

\begin{abstract}
*The author is a development economist with a D.Phil. degree form Oxford University and a former Senior Economist, Head of Macroeconomics and Development Policies Branch of UNCTAD. He is currently an international consultant, engaged in research and training in trade policy, WTO issues, industrial capacity building \& management of competitiveness, and diversification of oil exporting countries. He is affiliated to the Institute of Economic Research, University of Neuchatel, Switzerland.

This paper draws on and develops on the authors' recent studies, particularly: Trade Policy at the Crossroads; the Recent Experience of Developing Countries, Palgrave, Macmillan, 2005; "Towards an Alternative Perspective on Trade and Industrial Policies", Development and Change, 36(6), 2005: 1143-62, Is Industrial Policy Relevant in the $21^{\text {st }}$ Century, Arab Planning Institute, May 2006 and TWN,2008. Comments are most welcome and may be sent by e-mail: M.Shafaeddin@Gmail.com.
\end{abstract}




\begin{abstract}
The dissatisfaction of developing countries with the new Trade Round surfaced first in the WTO meeting in Seattle in autumn 1999. The Round was finally launched in Doha in 2001. Nevertheless, since the, the negotiations has faced with difficulties and deadlocks. The author argues that such difficulties are rooted in the economic philosophy behind the design of GATT/WTO rules and in their implementation by developed countries. The interrelated issues of conflict of ideology/interests and imbalances in the power relationship between developing and developed countries are the main cause of the inherent bias in the world trading system against developing countries. Such bias prevailed right from the time of the inception of the Breton Woods System as an alternative to the Keynes's proposal and the Havana charter. The combination of these factors has been reflected in a number of contradictions, double standards and asymmetries not only in GATT/WTO rules in favour of developed countries and their large corporations. It has also influenced the negotiation of developed countries with developing countries during the so-called "Doha Development Round"

The author refers to the particular example of negotiation on NAMA, in some details, to highlight inconsistencies between the objectives/spirit of the agreed text of the Doha Round and subsequent proposals made by developed countries. If these proposals were to be agreed upon they would limit policy space of developing countries necessary for their industrialization. It may, in fact, lock many of them in production and exports of primary commodities and at best, resource-based and assembly operations.

He further argues that unless these asymmetries are addressed, there will be a great risk of the collapse of the international trading system with its adverse socio-political consequences for the international community. Drawing on the experience of successful early and late industrializers and the failure of recent across-the-board and universal trade liberalization, he proposes the necessary changes in WTO rules commensurate with industrialization and development.
\end{abstract}




\section{Introduction}

The dissatisfaction of developing countries with the new Trade Round has seriously surfaced since the WTO meeting in Seattle in autumn 1999 and has led to a series of interruption in the negotiation process of the Doha Round in recent years. With the collapse of the talks between developed and developing countries in again July 2008, it is, in fact, faced with a deadlock. The purpose of this article is to explain that such a deadlock is rooted in the interrelated conflicts of interests/ideology and the imbalance in the power relationship between developing and developed countries. Such conflicts of ideology and imbalance existed right from the time of the inception of GATT, when the "development oriented" proposal by Keynes was turned down in favour of an alternative proposal by White, and has continued since then.

In terms of ideology, the origin of the problem goes back to Adam Smith whose universal theory of free trade was based purely on his "cosmopolitan approach". He did not distinguish differences between interests of individuals, nations and mankind as a whole and believed what was in the interest of Britain was also in the interest of the world as a whole. More recently, Samuelson (2004) has argued that if developing countries specialize in production and exports in accordance with static comparative advantage, the net real income of both developed and developing countries will improve. By contrast, if developing countries penetrate into exports of products in which developed countries had comparative advantage previously (he calls it dynamic fair free trade) developed countries would suffer loss in per capita income. In other words, "dynamic faire free trade" is not in the interest of developed countries.

The combination of the imbalance in the power relationship and the ideology/interests of the dominant powers have been manifested in a number of contradictions, double standards and asymmetries in the rules and regulations of the international trading system, practices of

3 to be checked 
developed countries and the process of trade negotiations in favour of developed countries and their corporations to the detrimental interests of developing countries They include, e.g.:

- Inherent contradictions in the design of GATT/WTO rules;

- Double standards reflected in contradictions between agreed rules and their implementations by developed countries;

- Inconsistencies between the objectives/spirit of the agreed text of the "Doha Development Round" and the position of developed countries during the process of subsequent negotiations exemplified by the case of NAMA in this paper.

If the proposals made by developed countries on NAMA are approved, it will limit, we will show, the policy space of developing countries in general, will halt upgrading of the industrial structure of those with some industrial capacity, and lock lower-income countries, with little industrial capacity, in production and exports of primary commodities, resources based industries and at best labour intensive products through assembly operations.

We will further argue that unless these asymmetries are addressed, there will be a great risk of collapse of the international trading system with its adverse socio-political consequences for the international community. On the basis of experience of successful industrializers and the failure of recent across-the-board trade liberalization, as prescribed by neo-liberals through "Washington Consensus" and international financial institutions, the author proposes the necessary changes in WTO rules in order to make them conducive to industrialization and development.

To proceed, we will first refer to the ideology and economic philosophy behind GATT/WTO rules. Subsequently, the general inconsistencies in design of the world trading system will be highlighted in section III. In the same section, some of the contradiction between the agreed rules and their implementation by developed countries will be explained. Sections IV and $\mathrm{V}$ is devoted to the process of NAMA negotiations and the implication of proposals made by 
developed countries for the industrialization of developing countries by drawing on the experience of early and late industrializers. The final section will conclude the paper.

\section{Ideology and economic philosophy behind GATT/WTO rules}

The philosophy behind GATT/WTO rules is the static version of the theory of cost comparative advantage which advocates universal free trade. This theory is strongly biased and influenced by ideology of its founder Adam Smith and his neo-liberal followers who advocate across-the-board trade liberalization. A number of famous neo-classical economists do admit that free trade is an "ideal" because the theory of CA is based on some unrealistic assumptions (e.g. Haberler, 1950: 227; Viner, 1953: 4-5; Corden, 1974: 7-8 and most important of all Samuelson, 1938: 266 and 1939:195). Yet in the end universal free trade remains the "religion" of neo-liberals, including the above-mentioned authors, "regardless of its lack of theoretical and empirical validity" (Subasat, 2003:163).

Adam Smith's theory of universal free international trade had three main characteristics: it was focused on the allocative functions of the markets, thus allocative efficiency, to the exclusion of their creative functions as instruments of economic change (Kaldor,1972: 1240); it was concerned with the expansion of international trade as against the development of "productive power"( economic development) (List, 1856:253 and Shafaeddin 2005.b); it was also concerned with maximizing the welfare of the world economy as a whole ignoring the fact that some nations may give more weight to their own welfare than the collective welfare of the mankind as a whole. The ideology behind his theory was that what was in the interest of Britain was also in the interest of the world at large (List, ibid: 245-6 and 261).

The ideology and bias in Adam Smith's theory is also strongly reflected on the new version of the theory of international trade based mainly on views expressed by Heckscher, Ohlin and Samuelson (H-O-S version) and more recently advocated through so-called "Washington 
Consensus". Allocative efficiency remains the main concern of neo-liberals but the development of dynamic comparative advantage remains out of their considerations. For example, Williamson (1999:19) clearly admits that "none of ideas spawned by ...development literature...plays an essential role in motivating the Washington consensus..." More importantly, the ideology and value judgment behind the neo-liberal theory is in no where clearer than in the contradictory remarks by Paul Samuelson the guru of free trade in his paper published more recently (Samuelson 2004) and his earlier papers published late 1930s-referred to in the previous paragraph. Earlier on he clearly stated that "some trade is better than no trade, but that does not necessarily imply that free trade is the optimum for any country" (Samuelson, 1938:266). This would imply that a developing country may not necessarily specialize according its static comparative advantage; it may develop some other industries to enter into production and exports of new (non-traditional) products). In his 2004, however, he argues that if a large developing country, e.g. China [or a group of developing countries], specialize in accordance with static comparative advantage, and the developing country (ies) manage(s) to improve productivity in these products, the net real national income of the developing country (ies) as well as the importing developed country (ies), which specialize in industrial products, will improve. Such a situation is regarded by him as an argument in favour of globalization (Ibid: 136). Nevertheless, if the developing country (ies) penetrate(s) into production and exports of goods in which a developed county (ies) previously had comparative advantage, by improving productivity in these goods [a possibility of developing and specializing in accordance with its dynamic comparative advantage] , the outcome will be different. In such a situation, the developed county (ies) will suffer permanent loss of per capita real income (Ibid. 137). Hence, he implicitly advocates that it is in the interest of developed countries that the developing country (ies) 
specialize(s) in accordance with its (their) static comparative advantage. In other words, the static comparative advantage indicates that a developing county can specialize in exporting what it already produces-not what it would like to produce and export.

The neo-liberals also extend the implication of the theory of static comparative to what the developing country "ought to" specialize in. The Samuelson's proposition is in contrast to views of the Gomery and Baumol (2000), Cline (1983), Amsden (1989).and Shafaeddin (2005.b).according to which free trade and specialization in accordance with static comparative advantage is not necessarily always to the advantage of a developing county. In the Samuelson's proposition China's improvement in productivity results from technical innovation which "takes place by imitation or home ingenuity" (Ibid: 137), but free trade still prevails. In the Gomery-Baumol postulation, dynamic comparative advantage is achieved through temporary protection and Government intervention. This formulation is closer to earlier argument by Samuelson that "some trade is better than no trade", but "this does not mean that free trade is always the best".

The implication of Samuelson's new argument is that faced with the possibility of penetration of developing countries into production and exports of products in which they have comparative advantage, developed countries (ies) have two different options: protect their market against imports of capital/technology intensive industrial goods from developing countries, or push developing countries to remain specialized in accordance with their "static comparative advantage". In practice, as far as manufactured goods are concerned developed countries are basically opting for the second option. They push developing countries to liberalize their trade regimes across-the-board and prematurely; 
they deny them access to new technology needed for upgrading of their industrial structure by protecting through Intellectual Property Right (TRIPS).

Further, for main products in which developing countries have static comparative advantage, i.e. labour intensive products, and particularly agricultural products, they have been protecting their own markets while universal free trade is advocated to, or imposed on, developing countries. The free trade ideology is applied to the extent that it is in the interest of developed countries. They do not practice what they preach. The contradictions in rules governing GATT/WTO agreements, inconsistencies between agreed rules and their implementation by developed countries, and in their proposals during the process of negotiations on NAMA are manifestation of such double standards.

\section{General contradictions}

\section{in GATT/WTO rules and their implementation}

Referring to the failure of international trade negotiation in Seattle in 1999, a distinguished Yale University Scholar pointed-out that: "what Seattle showed was that there is a lot more angst beneath the surface" ${ }^{\text {. }}$. This angst is basically related to differences between the interests of developed and developing countries in international trade. Right from the time of its inception of GATT; the Agreement concluded was biased in fovour of the former group. Further, the subsequent agreements, reached in the following trade rounds, have also suffered from inherent contradictions in terms and asymmetries influenced by double standards by industrialized countries. There are

\footnotetext{
${ }^{1}$ Jeffrey Garten, International Herald Tribune, 9 December 1999.
} 
contradictions in the design of GATT/WTO rules and inconsistencies between the agreed rules and their implementations by developed countries.

\section{i. The GATT Treaty of 1947}

To begin with, after the Second World War, two main proposals were on the table for drawing international rules on trade and payment systems and establishing the necessary international agencies. The Keynes proposal was "development oriented" as against "White proposal" which was more restricted in its scope. The latter was ultimately used as a basis for the Breton Woods system covering the World Bank, IMF and GATT. The Keynes proposal comprised of ITO (International Trade Organization), as an "indispensable" third pillar of the Bretton Woods system, and the creation of a world currency based on primary commodities. The Charter of ITO, known as Havana Charter, was negotiated and agreed in Havana under the auspices of the UN. ITO was supposed to be established as a specialized UN agency. The objective of the Havana Charter was not only to reduce tariff barriers but also, and more importantly, to attain"...the higher standards of living, full employment, and conditions of economic and social progress and development, envisaged in Article 55 of that [UN] Charter." (Para 3 of chapter 1 of the Havana Charter $)^{2}$. The Charter specifically refereed, inter alia, to the expansion of production, and industrial development "particularly of those countries which are still in early stages of industrial development", "access to the markets, products and productive facilities"[e.g. access to technology] and removal of restrictive business practices ( Chapter 1) as objectives of the ITO. The text of the Charter included detailed discussion

\footnotetext{
${ }^{2}$ The Havana Charter was negotiated through the UN Conference on Trade and Employment in Havana between 21 November 1947 and 24 March 1948. The Final Act of which was approved at the later date by the representative of 16 developed countries, including the USA, and 33 developing countries and territories who were present.
} 
of modalities for employment creation, cooperation for reconstruction and development, labour standards, commercial policy, reducing restrictive business practices, commodity agreements for stabilization of commodity prices, the operation of ITO and eventually the creation of a "Special Fund" in the UN, etc. The Charter was not, however, ratified by the US congress (Singer 1989:6-9 and UNCTAD, 1985).

In the meantime, in parallel to the negotiation on Havana Charter, the representative of 15 governments negotiated reduction of trade barriers which led to the GATT treaty signed initially by 23 countries in 1947 . The treaty was drawn mainly on the basis of the interest of the developed countries of the time (10 countries), although 12 developing countries and territories (mostly colonies) and Czechoslovak Republic were among signatories. The establishment of GATT, which came into effect outside the UN system, instead of ITO, meant that the Breton Wood system "remained incomplete... and distorted" (Singer, Ibid). It was "... a weak version, almost a caricature of the intended ITO"; it remained a "First World" institution as it did not make "allowance for special problems of developing countries"(Ibid: 6-7). The Bretton Woods system which was supposed to include UN, ITO, IMF and the World Bank was based only on the last two, and The GATT treaty was drawn only on the basis of the chapter of the Havana Charter which dealt with Commercial Policies aiming at reduction of trade barriers. Even then it was full of contradictions.

\section{ii. Contradictions and double standards}

Right from the beginning, the international trading system, based on the GATT Treaty, suffered from a number of inherent contradictions and asymmetries. Such systemic 
contradictions have also continued to manifest themselves in various forms in the subsequent negotiations and the results of various Trade Rounds as of today.

To begin with, the Preamble to GATT (1949) clearly refer to trade liberalization as the objective of the Treaty: “....[by] entering into reciprocal and mutually advantageous arrangements directed to the substantial reduction of tariffs and other barriers to trade and to elimination of discriminatory treatment in international commerce....have ....agreed....”. Hence, if international trade were to be liberalized free of discriminatory treatment, one would expect the existence of consistencies in GATT/WTO rules. Yet the GATT/WTO system contains a number of exceptional clauses which reminds oneself of exceptional clauses in the "Animal Farm" story. For example, first of all, according to GATT/WTO rules, the power and influence of the governments in the flow of international trade has to decline through reduction, or elimination, of tariffs and non-tariffs measures. Yet, the power and influence of TNCs in international trade is allowed to increase continuously. According to table 1, 500 companies accounted for about 70 per cent of world trade around year 2000. The cross-border mergers and acquisitions, which have accelerated since 1996, i.e. after the conclusion of the Uruguay Round, have also continued their high speed in recent years as shown in table 2. In fact, while the degree of concentration in international markets has increased significantly, the governments' controls on TNCs have been relaxed through TRIMs and GATS. According to Robert Wade:

These [international] regulations are not about limiting companies' options, as "regulations" normally connotes. Rather they are about limiting the options of developing country governments to constrain the options of companies operating or 
Table 1: The share of top firms in global production and trade (late 1990s)

\begin{tabular}{lcc}
\hline Activity & Number & Per cent \\
\hline All output & 200 & 28 \\
Industrial output & 1000 & 80 \\
World trade & 500 & 70 \\
\hline Source: Mooney (2000), 1-2:74. & &
\end{tabular}

Source: Mooney (2000), 1-2:74.

Table 2: Annual average cross-border mergers and acquisition with value of more than $\$ 1$ billion, 1987-2005

$\begin{array}{lcc}\text { Periods } & \text { No. of deals } & \text { value (\$billion) } \\ 1987-1996 & 23 & 49 \\ 1997-2001 & 110 & 445 \\ 2002-2004 & 71 & 186 \\ 2005 & 141 & 454 \\ 2006 & 172 & 584 \\ 2007 & & \end{array}$

Source: Based on UNCTAD ( 2007): table1.1. 
hoping to operate within their borders. In effect, the new regulations are designed to expand the options of developed country firms to enter and exit markets more easily, with fewer restrictions and obligations and to lock in appropriation of technological rents" ( Wade2005:80),

The large firms coordinate their activities not only outside the market, but they also shape the market and create barriers to entry for new comers. They coordinate their activities through strategic planning, strategic actions and vertical and horizontal relationship with other firms. Further, they have the capacity to influence production costs, prices, technology and the quality of goods they produce. They can target their market; influence the market structure and the environment within which they operate thus limiting the entry of new firms to the market.

The firm level economies of scale of large established firms are, in particular, important, not only because they are sources of cost advantage (which are different from factor cost advantages), but more importantly, because they are sources of "strategic behaviour", "dynamic competition" and progressive and cumulative changes over time. Such a Schumpeterian source of dynamic competitive process and power of "creative destruction" implies that the ability to export would depend on "comparative strategic advantage" rather than comparative cost advantage alone which is behind the philosophy of GATT/WTO rules ${ }^{3}$

Secondly, since the inception of GATT trade in manufactured goods has been subject to liberalization in various rounds of trade negotiations, but agricultural products have been largely excluded. According to OECD sources, the amount of producers

\footnotetext{
${ }^{3}$ For more details and references see Shafaeddin (2005.a): 9-14
} 
support paid in OECD countries in 2004 is estimated to be nearly 280 billion dollars (WTO, 2006:151) .When export subsidies added to this figure, the total amount of subsidies reaches about 1 billion dollars a day. The "cotton scandal", which cost livelihood of a large number of populations in rural Africa, is only one example of the problem (see below).

At the time the liberalization of the agricultural sector was under negotiation in WTO, the US delegation advocated, in the Food Summit in Rome in spring of 2008, further liberalization of the agricultural sector and preached "all countries to allow free flow of food..." Yet around the same time, the US congress passed the 2008 Farm Bill, which became law, increasing "trade distorting support" on 17 out of 25 agricultural products. Although the approved bill contains subsidies which are partly regarded non-distorting (Green Box subsidies), they have, in fact, trade distorting effects (SUNS, 19 May, 2008). The bill also provides subsidies to a couple with farm income of up to $\$ 1.5$ million (Ibid and SUNS, 5 June, 2008).

Susan Schwab, the US trade representative, said in early July 2008'it was unconscionable that developing countries were insisting on shielding their farms. " In the face of the food price crisis, it's ironic that the debate came down to how much and how fast could nations raise their barriers to imports of food" (dg Communities available at htpp//fdi.developmentgateway.org). But she does not consider unconscionable that more or less around the same time the US government passes a law approving agricultural subsidies of $\$ 56.8$ billion per annum, which amount to over 69 per cent of value of its agricultural exports in 2005 , and it is higher than the allocation of $\$ 49.5$ billion in the 2002 farm bill. 
Developed countries, justify support of their agricultural sector for social (income support for farmers) and strategic (food security) reasons. It is not clear why social considerations are relevant to farmers with income per head of $\$ 1.5$ million, but not to farmers of low-income countries with income of $\$ 1$ a day (per capita income of 366$)$.

Thirdly, even in the case of manufactured goods, products of interest to developing countries have been restricted either under exceptional arrangements until recently (e.g. textiles and clothing through certain arrangements in early 1960 and then through Multi-Fiber Arrangements, which came into effect in 1974) or through tariff escalations, safeguard measures and arbitrary anti-dumping practices (see zeroing below). While the average tariff on industrial goods in developed countries is low, tariffs on products of export interest to developing countries have been relatively high. This is because in the previous trade rounds, developed countries "have significantly reduced tariffs on the products of mutual interests among themselves", but continued to maintain higher tariffs on products of export interest to developing countries (Das 2005:34 -36).

Fourthly, According to the Uruguay Round (UR) Agreements, developing countries were forbidden to protect, or subsidize, their infant industrial exports selectively. Further, the TRIMs forbid theme to impose local content requirement, and obliges them to treat local and foreign companies equally-even though they lack equal capabilities. By contrast, developed countries benefit from infant industry protection of their new technology for over 20 years through TRIPS.

The double standard on protection is evident in the speech by the US representative to the ECOSOC in 2007 . He clearly defended the need for protection of 
technology: “...technological change is driven by protection [our italic] of IPRs [Intelectual Property Rights]. If we do not provide the incentives of IPRs, our technological progress will slow or dry up" (SUNS, 4 July 2007). It is not clear how change in the structure of exports of developing countries from primary commodities to manufactured goods does not need incentive through protection, but technological change does.

The Agreements on, the TRIPs, TRIMs, GATS and ASCM (the Agreement on Subsidy and Countervailing Measures) severely limit the policy space of developing countries (Shafaeddin (2005.b). Summarizing, the impact of the first three agreements, Wade concludes that: "With a touch of hyperbole the agreements [TRIPs,TRIMS and GATS] could be called a slow-motion Great Train Robbery” Wade (2005) (Ibid: 89).

Even Mr. Lamy, the Director General of GATT and former trade representative of EU, admitted, in his speech to ECOSOC on July the second, 2007, that: “....today a number of the current substantive rules of the WTO do perpetuate[our italics ] some bias against developing countries.

\section{iii. Implementation issues}

Developed countries did not fully implement even those rules to which they had agreed with through GATT/WTO. Examples of their double standards in what they have preached, and agreed with, and what they have been practicing are numerous before and after the Uruguay Round. The GATT agreement had been already eroded before the UR by the lack of respect for "unconditional MFN principle" and the non-reciprocity clause, in negotiation and dealings with developing countries, "managed trade" and unilateral action for "graduation" of developing countries which had benefited from GSP, resort to 
restrictive business practices, etc. Managed trade took place in the past e.g. through application of selective and discriminatory non-tariff measures, safeguards such as countertrade, subsidies unjustified anti-dumping measures and countervailing duties, etc. These selective protective measures inhibited market access, in particular of new and fast-growing suppliers with competitive products. Not only textiles and clothing but also some other products, such as iron and steel and automobiles, were subject to managed trade (UNCTAD, 1985:68-78). Only “....about 20 per cent of world trade was governed by the fundamental GATT instrument of unconditional MFN tariffs" (Ibid:75) 4 .

Examples of the lack of implementation of the UR agreement by developed countries are not few. Partial implementation of the Agreement on Textiles and Clothing (ATC) is a clear and important example. These products accounted for about 60 per cent of exports of manufactured goods of developing countries in late 1990s (WTO, 1998, tables 44 and 45). In contrast to the agreed schedule in the UR, developed countries left the bulk (49 per cent) of the quotas to be removed at the end of phase-out period (2005) most of which included high value added products ${ }^{5}$.

Another example is the use, by developed countries, of targeted exports subsidies and industrial policy which is restricted by Uruguay Round Agreements (URAs).

\footnotetext{
${ }^{4}$ The breakdown of the fixed exchange rate also contributed to the erosion of the GATT system as fluctuations in the exchange rate would result in the price of trade goods which often far exceeds the tariff rates, particularly in developed countries; for example a 20 percent depreciation of the dollar exchange rate would lead, cet par, to 20 per cent increase in price of imported goods to the USA which far exceeds the US average tariff rate of e.g. 6 per cent. The volatility in the exchange rate has in fact contributed to the tendency towards the use of flexible measures and managed trade(see UNCTAD, Ibid: 76-78), and chapter VI.

${ }^{5}$ For details and other instances of the lack of implementation of ATC by developed countries, see M. Shafaeddin (2005.c), chapter 8.
} 
Industrial policy and export promotion still prevails in various forms, including the use of tax holiday and subsidy, in most developed countries, including the United States, which is the most advanced industrial economy:

It can be argued that while the Washington Institutions stepped up their ideological crusade against government intervention in the Second and Third Worlds, domestically the US actually increased government assistance to business. The Small Business Administration financed 26,000 companies in 1992; in 1997, the number of companies receiving subsidised finance from this federal office alone had grown to 58000. While the Washington Institutions have managed the de-industrialisation of the Second and Third Worlds during the 1990's - under the theory that "all economic activities are alike" - within the US there is a plethora of government support programs specifically targeting manufacturing. Manufacturing industries with investments below 40 million dollars are eligible to receive loans at about 50 per cent of prime rate, subsidised by the federal government. At the last count, in July 1999, there were 821 different income tax credit schemes promoting investments in the real economy operating in the 50 states of the $\mathrm{US}^{6}$.

The dispute between the USA and EU on Government subsidization of exports of industrial goods by US companies, for which the Dispute Settlement Mechanism of WTO gave verdict against the USA Government, is yet another well known example (Reinert, 2000).It is estimated that in the fiscal year 1999, the USA provided $\$ 3.5$ billion worth of tax reduction to between 30000 to 7000 USA companies on about $\$ 250$ billion worth of exports. The companies benefited included such large ones as, GE, Boeing, IBM, Microsoft, etc. (Financial Times, 25 January 2007:7). Despite the verdict against the USA, wide spread subsidization of USA companies have continued. For example, $\$ 5$ b.in the form of aid and $\$ 10 \mathrm{~b}$ guaranteed loans were provided to airline companies after $9 / 11$,

\footnotetext{
${ }^{6}$ Reinert, (2000):18-19)
} 
or tax breaks worth of $\$ 3.4$ billion, and $\$ 2.5$ billion over 5 years, were provided to the oil companies and mining companies, respectively ${ }^{7}$.

Developed countries fulfillment of obligation under the URAs to improve market access was also inappropriate. For example in converting non-tariff barriers to tariffs, many developed countries took on tariffs levels higher than their non-tariff equivalent; in the case of tariff reduction they chose commodities with low tariffs for large percentage tariff reduction and those with high tariffs for small percentage reduction; the use of variable tariffs and non-ad-valuren tariffs became less transparent; the tariff rate quotas were implemented in a way that they made little contribution to market access for products of developing countries (Shafaeddin,2005.c:189-90).

In the case of agricultural products, according to the UR Agreement, the overall trade-distorting support of the US, which was supposed not to increase beyond 1992 level, was in fact increased from $\$ 16.3$ b in 2002, to nearly $\$ 19$ in 2005 (SUNS, 5 October 2007).

\section{The lack of compliance}

The lack of respect and/or compliance with the verdicts of Dispute Settlement Body (DSB) of the WTO is another example of the implementation of WTO rules by some developed countries, particularly the USA. The failure to respect the approved rules and verdict of the DSB not only undermines the integrity of the system, but also discredit it reducing the security and predictably of the world trading system. We will refer here only to two examples, the so called "cotton scandal" and Zeroing in antidumping operations.

\footnotetext{
${ }^{7}$ For details see Testimony of Ralph Nader Before the Committee on Budget, US House of Representatives, June 1999 and Boillier S. and Weissman (2007).
} 


\section{Cotton Scandal}

According to the Peace Clause of the UR Agreement (Part II, article 13.B (ii), the cotton subsidies should not exceed that of 1992 marketing year. But in practice the USA has continued ignoring the peace clause. In 2001/2 alone the amount of subsidies paid by the Government was \$3.9, double that of 1992 (Shafaeddin, 2005.c:190), or 130 per cent of the value of cotton production of the country! A quarter of the subsidy was received by one per cent of the richest US farmers (Ibid: 191). The corresponding amount of subsidy was over 3 times higher than total exports of cotton from least developed countries ${ }^{8}$ such subsidies were at significant loss of low cost, but poor countries. For example the resulting loss for 10 million African producers amounted to $\$ 301 \mathrm{~m}$ in $2001 / 2$. The loss for Mali, e.g., was equivalent of 1.7 per cent of the GDP and 9 per cent of exports of the country during the same period (op.cit).

The WTO Dispute Settlement Mechanism has ruled against the USA, in its verdict on the USA's cotton subsidies but there has so far been little change in the USA's practices. On $20^{\text {th }}$ June 2008, the DSB upheld the ruling of the Applet Body issued in 2004 in relation to a dispute brought by Brazil, initiated in 2003, on the use of subsidies on cotton and against which the USA had appealed. The DSB requested the US Government to bring its practices into conformity with its obligations under the Agreements on Agriculture and Subsidies and Countervailing Measures. Again the US representative was in disagreement with the verdicts of the DSB. More importantly, more or less at the same time, in defiance to the ruling by DSB, the US

${ }^{8}$ In 2007 the total cotton exports of developing counties amounted to about $\$ 4.5$ billion (UNCTAD, Statistical Handbook, 2008). 


\section{Congress passed "the 2008 farm bill", with little changes in subsidies in its "cotton incentive programme" contained in its 2002 farm bill. (SUNS, 23 June 2008).}

While we have referred to the case of USA, heavy subsidization of cotton exports is widespread by various developed countries. ${ }^{9}$.

\section{Zeroing practices in anti-dumping}

Developing countries are supposed to compete in international market. But when they develop their industrial base competitively, they are faced with arbitrary implementation of article VI of the 1947 GATT on duping. According to article VI, the existence of dumping per se does not permit an importing country to impose countervailing duties. It should be determined that it causes, or threatens material injury to domestic industries .Yet sometimes governments of developed countries impose countervailing measure arbitrarily ${ }^{10}$.Furthermore, the methodology applied for the calculation of the dumping margin continues to be flawed by "zeroing" in the case of the USA despite various verdicts of the DSB.

To explain, the dumping margin is the difference between the export price (fob) and normal value ${ }^{11}$ of a product. If the export price of a product to a destination is less than its normal value, dumping exists. Zeroing overestimates the dumping margins or even fabricates them. The department of Commerce of the USA calculates weighted-

\footnotetext{
${ }^{9}$ See Ibid: $190-94$ for details.

${ }^{10}$ Under certain conditions, it can be imposed ex-anti before the determination of the injury or threat of injury (article VI.c of GATT 1947)

${ }^{11}$ The normal value is "the comparable price, in the ordinary course of trade, for the like product when destined for consumption in the exporting country", or the highest comparable price for the like product for export to a third country, or the cost of production in the exporting country plus a reasonable selling cost and profit (para 1 of Article VI of GATT 1947).
} 
average of net prices (after allowing for transport and other business margins) of various transaction on .each imported product with the normal value of a product. In calculating the weighted average however, the negative dumping margins are set equal to zero i.e. in cases the selling price of an imported product is higher than its normal value; it is not taken into account. Thus the negative dumping margins are excluded from the calculation of the dumping margin.

It is estimated that in 17 determinations, out of a sample of 18, "....the dumping margin was inflated by zeroing. In 5 cases, the overall dumping margin would have been negative. On average, the dumping margins in the 17 cases would have been 86.4 per cent lower, if zeroing had not been employed" (Ikenson, 2004:2). Hence, Zerioing is a sort of selective protection tool which shields domestic producers from competitive imports.

EU accepted to refrain from zeroing as of 1998 after the first case was brought against it to the DSB. By contrast, in the case of USA, although so far 12 disputes have been brought against it, the Government has refused to implement any of the rulings. It has continued zeroing regarded illegal by DSB. The US Government often has challenged the verdicts with the pretext of existence of flaws in the argument of the Appellate Body. The latest example is the verdict of the DSB on 20 May 2008 on ruling of the Appellate body of 30the April 2008 regarding a case brought to the DSB by Mexico on exports of stainless steel. More importantly, not only it has opposed banning zeroing, but “...influential congressmen and senators have made it clear that there would not be Doha deal, if it did not have changes in the WTO rules to allow for 'zeroing"(SUNS, 15 May 2008). 
Generally speaking, there is a lot of difference between what developing countries preach developing countries to do and what they actually do themselves. According to an ex-USA official: “...[president ] Regan himself, despite his devotion to open market in general and free trade in particular, granted more income relief to US industry than any of his predecessors in more than a century" ( Bergsten, 2001:8) ${ }^{12}$.

In nutshell, while developed countries preach developing countries to liberalize, they have tried to avoid it themselves in many cases. The Nobel Prize winner, Professor Stiglitz, once said: "I found myself in uncomfortable position of an American saying "do as we say, not as we do". The case of NAMA is also a clear reflection of such a double standard in the position of developed countries during the course of the negotiation in the Doha Round.

\section{NAMA negotiations}

The development orientation of the Doha Round is undeniable if one bases his judgment on the stated objectives of the Round as contained in the Doha Ministerial Declaration and its related Work Programme. Yet there are clear inconsistencies between the agreed Doha Text and the subsequent proposals made by developed countries during the process of negotiations on NAMA the contents of which are to the detriment of industrialization of developing countries. Such inconsistencies give the impression that in fact there has never been genuine intention for having a development oriented Round. According to an editorial in International Herald Tribune, the Doha Round was "sold as the "development round'. But in practice, it was turned into "market access" round by developed

\footnotetext{
${ }^{12}$ based on remarks by Treasury Secretary James A. Baker before a conference sponsored by the Institute fro International Economics (14 September 1987).
} 
countries $^{13}$. This statement is confirmed by Charlene Barshefsky, previous US trade representative who was involved in the Doha meeting. According to her the wealthy

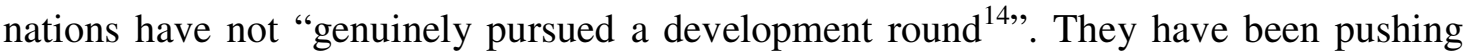
developing countries to cut tariffs on their industrial and agricultural goods, and services substantially and reduce restrictions on activities of multinationals in exchange mainly for a slight cut in their tariffs on industrial goods and in their domestic supports for agriculture. The comparison of the stated objectives of the Round with the position of developing countries during the subsequent negotiation until the collapse of the talk in July 2008 is a proof of Barshefsky 's statement and an indication of the loss of policy space of developing countries if the proposals of developed countries are agreed upon.

\section{Stated objectives of the Doha Round}

The emphasize put on the development orientation of the Doha Round in general is evident in a number of passages of the Doha Ministerial Declaration. For example, according to paragraph 2 of the Declaration, "We seek to place their needs [developing countries needs] and interests at the heart [our italics] of the Work Programme adopted in this declaration". Similarly, article 6 of the same declaration emphasizes that: "We strongly reaffirm our commitment to objective of sustainable development, as stated in the preamble to the Marrakesh Agreement". These passages reinforce earlier GATT/WTO rules and decisions in which the special need of individual developing countries and industries are recognized (e.g. Article XXVIIIbis of GATT 1994, and para8

\footnotetext{
13 "Trade talks that were meant to help the poorest", International Herald Tribune, 22.10.2007: p.6.

${ }^{14}$ See "Charlene Barshefsky on Doha", International Herald Tribune, Managing Globalization "Business Blog", 31, January 2007.
} 
of Article XXXVI, part IV, GATT 1994). On the particular issue of NAMA paragraphs 16 and 50 of the Doha Declaration clearly refers to a number of principals to be followed during the curse of negotiation in order to attain a favourable outcome for developing countries. Accordingly, the negotiations shall take full account of "the special needs and interests of developing and least developed country participants..." including:

- Less than full reciprocity in tariff reduction commitments in favour of developing countries;

- Special and differential treatment for developing and least developed countries as stated in part IV of the GATT 1994, etc.;

- Reduction or elimination of tariff peaks, high tariffs and tariff escalation, as well as non-tariff barriers, in particular on products of export interest to developing countries.

Para 3.b of Article XXVIIIbis (GATT 94) also clearly refers to "the needs of developing countries for more flexible [our italics] use of tariffs protection..." Further, the July 2004 package again emphasizes the principles of "less than full reciprocity" and "flexibility" in favour of developing countries (e.g. paragraphs, 3,4 and 8 of Annex B to the text of the July 2004 Package $)^{15}$. Flexibility would allow a percentage of tariff lines deviate from the full extent of the formula cuts or be exempted from them. In addition, Para 94 of the Hong Kong Ministerial Declaration refers to proportionality, or balance between ambition levels between NAMA and Agricultural market access. The latter also implies that the principals applied to NAMA should be consistence with those applied to Agriculture.

${ }^{15}$ See Khor, M. and Yen, G.C. (2005) for details. 
The position of developed countries during the course of negotiation

In practice, however, the proposals made by developed countries during the negotiation on NAMA are neither conducive to industrialization and development nor consistent with those principles.

In fact, right after the conclusion of the Doha Declaration, developed countries deviated from the objectives of the Doha Round by making proposals which were not in the interests of developing countries as contained in the Annex B of the July 2004 decision. This Annex contained elements of less than full reciprocity and Special and differential treatments in favour of developed countries. It was pushed through by the chairman of the negotiating group to be sent to the General Council despite the opposition by developing countries. The contents of Annex B was, in effect, legally nullified by the paragraph 1 of the Annex which regarded them as issues for further negotiations rather than agreed decisions (Das, Ibid:29-30). Nevertheless, developed countries have continued, more or less, on the basis of their original proposals contained in the remaining articles of Annex B (Articles 2-17), until the collapse of the talks in July 2008. Between July 2004 and July 2008 a number of new "chairman texts" have been issued but the content of none of them has been development ${ }^{16}$. Developed countries have been pushing for across-the-board liberalization of trade in manufactured goods by applying the (non-linear) Swiss Formula for cutting and bounding individual tariff lines at low level, by limiting flexibility and requesting "anti-concentration" in tariff cuts and by asking for compulsory "sectoral initiatives". They have often ignored the views

\footnotetext{
16 Since then the Chairman presented new texts in July 2007, 8 and 28 February 2008, 18 May and July 2008. Further, Mr Lamy, the Director-General of WTO, presented his own text on 25 July 2008 before the talks collapsed once again.
} 
expressed by delegations of developing countries, to the extent that certain clauses were inserted in the draft negotiating texts presented by the chairman of the NAMA without much prior discussion. Further, the use of time pressure, threats, bulling and blame games have been among tactics used by developed countries.

The choice of the Swiss Formula, vis-à-vis a linear formula, and its coefficients, and flexibilities in tariff cuts have been subject of hard negotiation.

\section{The implications of the Swiss Formula}

The Swiss formula proposed in July 2004 text and used for negotiation for tariff cuts, despite reluctance of developing countries, is a non-linear formula as follows:

$$
\begin{aligned}
& \mathrm{T}=(\mathrm{a} \cdot \mathrm{t}) /(\mathrm{a}+\mathrm{t}) \text { and } \\
& \mathrm{R}=\mathrm{t} /(\mathrm{a}+\mathrm{t})
\end{aligned}
$$

where "T" and "t" and "a" are the new and initial tariff rates and constant coefficient, respectively, and $\mathrm{R}$ is the rate of tariff reduction.

This magic and complicated Swiss formula has a few main characteristics which are inimical to industrialization of developing countries:

- . the coefficient (e.g. 15), determines the maximum tariff rate possible under the formula irrespective of the country's present tariff rates and level of industrialization,

- the lower the coefficient, the higher will be the rate of reduction in tariff,

- for a given coefficient, the higher the initial tariff rate, the higher the rate of reduction in tariff, 
- for high tariff rates the rate of reduction in tariffs is higher than when a simple linear formula is applied (in which case the same percentage reduction is applied to all tariff lines).

- in a certain range of low tariff rates, the formula will lead to lower rates of percentage reduction than those generated by a tariff-independent linear reduction $^{17}$.

According to the initial proposals made by developing countries, all countries were supposed to apply the same (Swiss) formula to cut average tariffs rates drastically and reduce their dispersion by binding 95 per cent of their all individual tariff ${ }^{18}$ lines at the same rate at the low levels. For example, the USA proposed that developing countries cut tariffs to 8 per cent by 2010 and reducing them to zero by 2015. Certain sectors were proposed to be subject to zero tariffs immediately upon the conclusion of the Doha Round. The EU proposed non-linear cuts in tariffs according to the Swiss formula and a low and uniform coefficient of 10 chosen for both developed and developing countries. Their proposal following the Hong Kong Ministerial Meeting (2005) was to apply coefficients of 15 for developing and 10 for developed countries, receptively ${ }^{19}$. With coefficient of 10 for developed countries, a tariff rate of 5 per cent will be reduced to 3.33 per cent-a reduction of 33 percent, but only 1.67 percentage point. By contrast, a coefficient of 15 per cent for developing countries will reduce a tariff rate of 50 per cent

\footnotetext{
17 For details see Shafaeddin (2006.a).

${ }^{18}$ Five per cent of tariff line can be excepted provided the related imports do not exceed 5 per cent of the total value of member's imports (para 8, annex B of the WTO July 2004 Package).

${ }^{19}$ It is also proposed that at least 95 per cent of their individual tariff lines be bound.
} 
to 11.5 per cent a reduction of 38.5 percentage point and76 per cent. It is clear that the choice of the formula as well as its coefficients would results in less than full reciprocity in tariff cuts in favour of developed, not developing countries.

Since July2004, new coefficients have been proposed, but still remain biased against developing countries. In the July 2007, the chairman proposed the coefficient of 8-9 for developed countries and 19-23 for developing countries. The tariff cuts were to be implemented in 5 years and 9 years by developed and developing countries, respectively.

Trade off between the coefficient and Flexibility in tariff cuts

Further, allowing higher coefficients (lower tariff cuts) to developing countries required the trade-off with flexibilities in tariff reduction and binding. In other words, the number of tariff lines sheltered from formula cuts could be a positive function of percentage of formula cuts on those line; the higher the cut (the lower the coefficient), the higher the flexibility (the higher could be the number of tariffs lines exempted from full formula cuts). Accordingly, with coefficients of $19-23,5 \%$ of tariff lines can be left unbound provided they do not represent more than $5 \%$ of imports of non-agricultural products of the country. Alternatively, $10 \%$ of tariff lines can be exempted from half formula cut provided they do not represent more than $10 \%$ of their non-agricultural imports. Countries which are prepared not to use any flexibility can apply higher coefficient of 2226 i.e. 3 points higher than otherwise required (19-23).

The July 2007 text also provides some exceptional clauses and extra flexibilities for least developed, small and vulnerable economies and recently 
acceded countries in applying tariff cuts and binding. Nevertheless, they are not sufficient to satisfy the needs of these countries for industrialization or upgrading of their industrial base ${ }^{20}$. For example the simplification of the cumbersome rules of origins is not considered.

Developed countries criticized the July 2007 text on the ground that developing countries are requested to cur tariffs little!! Developing countries requested a minimum of 25 points difference in the coefficients applied to them and to developed countries as well as significant flexibilities in tariff cuts. Their views were ignored in the subsequent chairman's draft texts, including his July 2008 text and finally in Mr Lamy's draft of 25 July 2008 before the talks collapsed.

Mr. Lammy, the head of the WTO secretariat, also acted also as a chairman of TNC (Trade Negotiating Committee), in proposing a package consisting of coefficients of 8 for developed countries and an option of 20, 22 and 25 for developing countries. These coefficients were only the mid points of those proposed by the chair in his July 2008 text. The flexibilities in tariff cuts would vary depending on the coefficient used:

for the coefficient 25 ,there would be no exemption to cutting tariff lines,

for coefficient 20 it would contain two alternatives: exemption of 14 per cent, or $6.5 \%$ of tariff lines from full formula cuts, provided they would

\footnotetext{
${ }^{20}$ For details see South Centre (2007), particularly pp 30-34.
} 
not represent more than 16 per cent, or $7.5 \%$ of imports of manufactured goods respectively

for coefficient $22,10 \%$ of tariff lines would be exempted from tariff cuts provided they would not represent more than 5\% of imports of manufactured good.

The difference between coefficients of 25 and 20 is not significant. Taking into account the average tariff rate of 30 per cent for developing countries, the new tariff would be $13.6 \%$ and $12 \%$, respectively; they would lead to $54 \%$ (or 16.4 percentage point) and $60 \%$ (or 18 percentage point) cut in tariffs of developing countries, respectively . By contrast, the coefficient of 8 would lead to a reduction in simple average tariffs of developed countries from about $3.7 \%$ to $2.5 \%$ ) by about $31 \%$ (or only 1.2 percentage point $)^{21}$. The comparison of these calculations reveals that the outcome is again absolutely the reverse of the less than full reciprocity for developing countries. It basically leads to leads to enhanced market access for developed countries.

It is interesting to note that in defiance of the agreed rules of GATT, the chair claimed that there had never been "agreed definition of reciprocity". The notion of reciprocity and less than full reciprocity in treating developing countries is, in fact, clear in the Decision of 28 November 1979 of GATT (see Appendix A).

Further, Mr. Lamy's proposals also limited flexibilities further by linking flexibilities (and coefficients) to the so-called "anti-concentration" clause and "sectoral

\footnotetext{
${ }^{21}$ Taking into account the average tariff rates of 3.9,3.2 and 2.3 for the EU, the USA and Japan, respectively, it corresponds to $33 \%$ ( 1.3 percentage points) for EU; $29 \%$ (1 percentage point) for the USA and $22 \%$ (1.6 percentage point) for Japan.
} 
initiative" which were initially introduced by the chairman in his July 2008 text. According to anti-concentration clause, developing countries must not exclude from any formula cuts a whole sector or a proportion of tariff lines in the sector beyond s certain level. For example, it is proposed that $20 \%$ of tariff lines with at least $9 \%$ of total import value in any sector (or HS chapter) must be subject to full formula cuts. The implication of this clause is that various parts and components necessary for development of an industry can not be protected.

The sectoral initiative, was supposed to be non mandatory; it means contracting parties should voluntarily reduce tariffs in some sectors to zero or near zero. In practice, in the 18 may draft modalities introduced by the chair of NAMA, it was linked to flexibilities. In other words, to acquire extra flexibility (or a higher coefficient), a country ought to participate in sectoral initiative.

Hence, the Swiss formula with a low coefficient fits the interests of the developed countries, while it goes against the developing countries' interests. The latter would be subject to significantly greater reduction in their tariff rates in terms of percentage as well as percentage points Even with the latest coefficients and flexibilities proposed By Mr. Lamy, the policy space of developing countries will be limited, there will be less than full reciprocity and special and different treatment in favour of developed countries. It is true that the initial tariffs of developed countries are much lower than those of developing countries, but developing countries do need higher tariffs on industrial products as will be mentioned shortly. 
Arbitrary insertion in the draft modalities, by the chairman, threat, bulling and blaming have been other tactics used by developed counties. For example, the views expressed by the chairman in various draft modalities (e.g. July 2007 text and 8 February and 28 February 2008 texts) were attributed to the majority of members. Yet, developing countries did not confirm this statement and regarded some of issues included in his texts arbitrary as they had been hardly discussed in the formal meeting. Hence, they were regarded as "coffee shop" proposals.

An example of threat and bullying is that made during the course of negotiation in July 2008 when anti-concentration and sectoral initiative was introduced and discussed. The US and EU representatives threatened that unless these issues were accepted by developing countries as drafted by the chairman, they would not agree to opening brackets in the text on other issues on which progress had already been made ${ }^{22}$ Another example is their threat that without successful NAMA outcome, there would be no reduction in agricultural subsidies, no liberalization in services, no advance in trade facilitation, and no development round ${ }^{23}$.

Finally, while developed countries did not show much flexibility during the negotiation, each time it was interrupted, they blamed a number of developing countries engaged in small-group discussions. Further, while developed countries insisted on limiting flexibilities in tariff cuts in negotiation on NAMA, they

\footnotetext{
${ }^{22}$ See "Divisive issues throw shadow over NAMA state of play" in the SUNS (South-North Development Monitor), 9 July 2008.

${ }^{23}$ Ibid, 30 May 2008.
} 
requested far greater flexibilities in tariff reduction as well as restricting subsidies in the course of negotiation for liberalization of agriculture.

Implications for industrialization

The application of the proposed coefficients suggested by developed countries will have a significant detrimental long-term effect on industrialization of developing countries, with no negative effects on developed countries. Developed countries are already industrialized; they have the supply capacity to produce capital-intensive, skillintensive and technology-intensive goods. By giving up some-in fact in this case small trade barriers on imports in exchange for market access in developing countries, developed countries do not sacrifice their long-run industrial development. Of course, their upgrading of the industrial sector depends on the development of new technology. But they have firmly secured protection of their new technologies through the WTO's TRIPS Agreement as mentioned in the previous pages.

By contrast, the use of tariffs is almost the only remaining trade policy instrument for developing countries. Yet the industrial sector of most developing countries is, unlike that of developed countries, underdeveloped. Thus, they need to apply higher tariffs to some of their industries, particularly new ones. The low and bound tariffs rates being proposed will disarm them of an important policy tool for establishing new industries and upgrading the existing ones. Clearly, by obtaining further market access in developed countries, they will improve the prospects for expanding exports for their existing efficient industries, i.e. industries in which they have static comparative advantages. But binding tariffs at low levels deprives them of the tool of diversification and expansion of 
supply capacity in new industries in which they may wish to develop dynamic comparative advantage. Therefore, even when market access is provided for such potential products, the prospects for their supply expansion will be absent due to the lack of policy space. In other words, for the sake of better access to markets for their current export products, they sacrifice the ability to establish new industries or diversify their production structure away from primary commodities or upgrade their manufacturing sector into new products. Such a trade-off will result in deepening of their static comparative advantage.

Professor Wade correctly argues that "International rules should be judged against how they assist or hinder production diversification" (Wade2006: 8), not specialization according to static comparative advantage. Otherwise, whatever efficiency is gained due to liberalization will be at the cost of growth and diversification in the long-run. $\mathrm{He}$ is also correct to say that WTO rules makes the "creative function" of the markets more difficult by hindering diversification and upgrading of the production structure in developing countries; but they encourage industrial upgrading in industrialized countries as they "permit industrial policy activism of the kind needed to nurture 'knowledgeintensive' industries and activities" which prevail in developed countries! (Wade 2006: 89). The protection of technology intensive industries through TRIPs is a clear example of such encouragement as mentioned earlier.

Before ending this section, note that applying the CGE models in their simulations, the neo-liberals conclude that developing countries are the major winner of the simulated Doha scenarios (e.g.Kimman and Lodefalk, 2007 and Bouet et.al, 2007). These models, however, are based on restrictive and unrealistic assumptions and static 
comparative advantage theory disregarding the need for supply capacity building in accordance with the principle of dynamic comparative advantage.

\section{Lessons from History}

The experience of successful industrializers and premature liberalization in colonies and in developing countries, in more recent years, provide us with lessons from history indicating that across-the-board and premature liberalization will lead to deindustrialization (Shafaeddin (2005.a and 2006.b). The experience of successful early and late industrializers indicates first of all that with the exception of Hong Kong, no country has managed to industrialize without going through the infant industry protection phase, although across-the-board import substitution and prolonged protection have also led to inefficiency and failure ${ }^{24}$.

Secondly, government intervention, both functional and selective, in the flow of trade and in the economy in general has played a crucial role in the process of industrialization. In all cases, including Great Britain, industrialization began on a selective basis, although to a different degree, and continued in the same manner until the industrial sector was consolidated.

Thirdly, when their industries matured, they began to liberalize selectively and gradually. Therefore, trade liberalization is beneficial after an industry reaches a certain level of maturity provided it is done gradually and selectively. In contrast, premature

\footnotetext{
${ }^{24}$ The following paragraphs are based on Shafaeddin (2006.b).
} 
trade liberalization, whether during the colonial era or in more recent decades, has had disappointing results. For example, when the USA tried to liberalize pre-maturely in 1847-61, the industrial sector suffered and the country had to revert to protectionism against imports from Great Britain.

Fourthly, government intervention was not confined to trade; the state intervened through other means, directly and indirectly, in particular to promote investment and to develop the necessary institutions and infrastructure. Industrialization was also supported by attention to and growth in agricultural production. Hence, the issue is not the lack of intervention, but the nature and the efficiency of intervention.

Fifthly, while different countries did not follow exactly the same path, all learned from the experience of others; the USA learned from Great Britain, Germany from the USA, Japan from Germany and the Republic of Korea from Japan, etc.

Sixthly, all main early industrializers tried to open the markets in other countries when their industrial sector matured. In the 19th century, free trade policy was forced on the colonies and the 5 per cent rule (according to which 5 per cent was the maximum tariff rate allowed on any import item) was imposed on semi-colonies and independent countries through "unequal" bilateral treaties and/or through force (for example, in China, after the opium war of 1839-42).

Further, the policy space of the colonies, in the 19th century, was further limited by England by outlawing high value-added manufacturing activities in the colonies and banning the export of competing items from colonies to England (Chang2005.b). Instead, 
production of primary products was instituted and promoted. The outcome of the imposition of pre-mature trade liberalization on the colonies was devastation and led to de-industrialization. For example over 90 per cent of textiles industries of India were destroyed as a result of liberalization by the colonial power.

\section{Recent experience}

During recent decades, developing countries have been pushed through multilateral organizations and bilateral trade agreements to open their markets. In addition, tariff peaks and escalation and arbitrary anti-dumping measures have been among the means of restricting imports of high-value added products from developing countries. The results of a study, by the author, of about 50 developing countries which have undertaken trade liberalization during the 1990s indicates that with the exception of East Asia, their trade liberalization has had three main features which are common with the proposals of developed countries in NAMA negotiations:

- Uniformity: i.e. a tendency toward uniform tariff rates for various industries in each country;

- Universality, i.e. application of the same recipe to all countries irrespective of their level of industrialization and development;

- Premature and rapid liberalization.

The results of this kind of liberalization have been disappointing for most of the countries other than those in East Asia. Firstly, only 20 countries, or $40 \%$ of the sample, 
have shown high (more than $10 \%$ a year) rate of growth of exports of manufactured goods. And of these, only in about 10 countries (mostly in East Asia) were high growth rates of exports accompanied with increasing or high growth rates of Manufacturing Value Added (MVA). MVA is a more important indicator of performance than export, as it measures the net output or income accruing to the country, whereas a rise in exports could also be accompanied by a corresponding or even higher rise in imports (including of inputs that are used in the production of exports).

Secondly, and more importantly, in fact, in half of the sample countries deindustrialization took place over 1980-2000. The premature fall in MVA/GDP ratio is taken as an indicator of de-industrialization. This ratio declined without recovering to the initial level. In many countries industrial employment also suffered severely.

Thirdly, when exports expanded, this growth was mainly in resource-based industry and some assembly operation without much upgrading, except for industries which were dynamic during the import-substitution era and were near the stage of maturity, or which continued to benefit from some sort of support from the government. The aerospace industry of Brazil is a good example of an industry which was near the stage of maturity and benefited from liberalization.

Fourthly, even though the relative incentives changed in favour of exports, the manufacturing industry suffered from low investment despite a significant increase in foreign direct investment in some cases (for example, Brazil). Investment in manufacturing suffered because the balance of risk and return turned against the manufacturing sector (Shafaeddin, 2006.b). 
The above survey results add to the conclusion that low and uniform bound tariff rates, particularly if it tends to zero in the next round, would imply the end of industrialization of many developing countries; and it would prevents the upgrading of the industrial structure of others.

If so, developing countries have not lost anything by the collapse of the talks. Further, they will not lose anything if the resumption of the talks is to lead to the acceptance of the proposal made by developed countries on NAMA. These proposals, if agreed upon, would lock the structure of production and exports of the majority of developing countries into primary commodities, simple resource-based and labour intensive products and at most assembly operations. The developed countries proposals on services and agriculture are not much different as far as development of developing countries is concerned.

One should not confuse ends with means. An agreement, should serve the purpose of development, it should not be concluded simply for the sake of having an agreement; development should not be sacrificed for reaching an agreement. The failure to reach a bad or damaging agreement will in fact be a success for development. However, developing countries should not accept being bullied to unequal bi-lateral free trade agreements either.

In developing countries, different industries require different rates of protection and different lengths of time for their development. This is because there are differences in risks and scales of production involved in different industries which also need different length of time and experience for their technological upgrading. Another problem is that uniform tariff rates provide different effective rates of protection for various industries, 
depending on their import intensity. For given uniform rates for output and inputs, the higher the import intensity, the lower the effective rate of protection. As a result uniform rates involve biases against new industries as new industries usually have high import intensity. This explains why assembly operations do not easily lead to increases in value added.

\section{Concluding Remarks}

The Doha Round was supposed to be a Development Round, but in practice, it was turned into "market access" round by developed countries in their own favour. Developed countries were pushing developing countries to cut tariffs on their industrial and agricultural goods, and services substantially and reduce restrictions on activities of multinationals in exchange mainly for a slight cut in their tariffs on industrial goods and in their domestic supports for agriculture. Therefore, while developed countries would gain significant market access in developing countries particularly for manufactured goods, developing countries would lose their policy space to develop their industry in accordance with the principal of "dynamic comparative advantage". Of course, they would gain some market access for products for which they have static comparative advantage. But it would be at the cost of their diversification and development in the long-run. This is the gist of the problem which is also related to the philosophy behind GATT/WTO rules based on the Neo-classical static comparative cost advantage theory.

As long as the philosophy behind GATT/WTO is not changed and the related contradiction are not dealt with "do not hold out hopes for the Doha Round" or fair treatment of developing countries in the future. What is needed first of all is that before 
conducting trade negotiation, developing countries should have a clear concept of their industrial development strategy and trade policy. This is a necessary condition. However, it should be emphasized that any intervention might not serve the purpose of diversification and upgrading. For this purpose the decision making capacity of the government should improve to enhance the efficiency of its policy making mechanism. While a country may learn from the experience of others, it can not copy them; each country has its own characteristics which may be different from others to some extent.

The sufficient condition is that the rules of the World Trading System should be changed in a way that would allow a dynamic and flexible trade policy with dimensions of space and time according to which the trade rules would ${ }^{25}$ :

Accommodate countries with different levels of industrialization and development at each point in time, therefore allowing "Special and Differential Treatment" as a rule not as an exception;

Therefore, the concept of "less than full reciprocity" should be taken more seriously as countries are at different levels of development and have different needs;

Allow change of trade policy in each country as the country develops; hence a country should be allowed the necessary policy space for both selective infant industry protection and gradual and selective liberalization, when an industry reaches near maturity;

${ }^{25}$ For details see Shafaeddin (2005.b), and Wade (2006)10-13. 
For liberalization of the tariff structure, flexibility would dictate that only average tariffs (which may be even higher than the current average rate) are bound with significant dispersion (Akuz 2005);

Permit the use of export performance requirements by developing countries in TRIMS;

$>$ Let easier transfer of technology to developing countries by changing TRIPS Agreement and revising Subsidy and Countervailing Measures Agreement and GATS to provide more policy space for developing countries.

Of course, such a re-conceptualization of the trading system will not take place over night, but it eventually need to happen (Helleiner, 2005). The problem, according to C. Barshefsky, the former US trade representative, at the moment is that "the developing world is not hearing what we are saying and we're not hearing what developing world is saying. We are passing [each other] like ships in the night". Yet developing countries are often blamed for the lack of progress in the trade talks. There is no need to put first priority on concluding the negotiations simply to avoid blame for the "failure", if the results of the negotiations are a recipe for their countries' de-industrialization. But the failure of talks should not lead to the acceptance of unfavourable bilateral agreements, which are often more stringent than multilateral agreements. 
Appendix A:

$\underline{\text { The Decision of } 28 \text { November } 1979 \text { on Differential and More }}$

Favorable Treatment, Reciprocity and Fuller Participation of developing Countries.

The developed countries do not expect reciprocity for commitments made by them in trade negotiations to reduce or remove tariffs and other barriers to trade of developing countries, i.e. the developed countries do not expect the developing countries, in the course of negotiations to make contributions which are inconsistent with their individual development, financial and trade needs. Developed contracting parties shall therefore not seek, neither shall less-developed contracting parties be required to make, concessions that are inconsistent with the latter's development, financial and trade needs" 


\section{References}

Akyuz, Y. (2005), "The WTO negotiations and Industrial Tariffs: What is at Stake for Developing countries? (Third World Network, Geneva)

Amsden, A. H. (1989), Asia's Next Giant, South Korea and Late Industrialization (New York, Oxford University Press).

Gomery, R. E. and Baumol, W. J. (2000), Global Trade and Conflicting National Interests (Massachusetts, Massachusetts Institute of Technology).

Bergsten, C. F. (2001), “Fifty Years of Trade Policy: the Policy Lessons”, Journal of World Trade Law, 1- 13: p. 8 based on remarks by Treasury Secretary James A. Baker before a conference sponsored by the Institute fro International Economics (14 September 1987).

Barshefsky C.(2007) "Chrles Barshefsky, on Doha”, International Herald Tribune, Managing Globalization "Business Blog”, 31, January 2007.

Boillier S. and Weissman, R, "US gave huge industrial subsidies ,while now proposing WTO ban", SUNS, 16 July 2007.

Bouet, A.,Mevel,S.and Orden,D.(2007), “"More or less Ambition in the Doha Round: Winners and Losers from Trade Liberalisation with a Development Perspective", The World Economy:1253-80.

Chang, Ha-Joon (2005) Why Developing Countries Need Tariffs; How WTO NAMA Negotiation could Deny Developing Countries' Right to Future, South Centre, Geneva.

Cline, R. W. (1983), Trade Policy and Economic Welfare (Oxford, Clarendon Press).

Corden, W. M. (1974), Trade Policy and Economic Welfare (Oxford, Clarendon Press).

Das, B.L. (2005), The Current Negotiations in WTO, Options, Opportunities and Risks for Developing Countries (Geneva, Zed Books and TWN):34 and 36.

Haberler G. (1950), "Some Problems in the Pure Theory of International Trade", The Economic Journal, 60, 223-406.

Helleiner, G. K.(2005) "Markets, Politics and globalization: Can the Global Economy be Civilized?", $\quad 10^{\text {th }}$ Raul Prebisch Lecture, Geneva, UNCTAD. 
Ikenson, D(2004), " Zeroing IN: Antidumping's Flawed Methodology under Fire", Centre for Trade Policy Studies, Cato Institute, Trade Bulletin No. 11

Kaldor,N.( 1972): 1240); it was concerned with the expansion of international trade as against "productive power"( economic development).

Khor, M. and Yen, G.C. (2005), "The WTO Negotiation on Non-Agricultural Market Access: A Development Perspective" a paper presented to a Workshop on NAMA organized by TWN, Geneva, 9 May $2005: 10-12$ for details.

Kinman, S. and Lodefalk, M.(2007), "What is at stake in the Doha Round?", The World Economy, 1305-25.

List, F. (1856), The National System of Political Economy, translated by Matile, G. A. (Philadelphia, J. B. Lippincott \& Co.).

Mooney, P. R. (1999), "Concentration in Corporate Power on the Coming Binano Republic", Development Dialogue, 1-2.,73-114

Reinert, F. S. (2000), The Other Cannon: The Other Cannon and the History of Economic Policy, Norsk Investor Forum and SVN (Oslo, University of Oslo, Centre for Development and Environment).

Samuelson, P. A. (1938), "Welfare Economies and International Trade", American Economic Review, 261-66. Reprinted in Stiglitz, J. E. (1966), The Collected Scientific Papers of Paul A. Samuelson (Cambridge, M.A., MIT Press).

Samuelson, P. A. (1939), "The gains from International Trade", Canadian Journal of Economies and Political Science, V, 195-205. Reprinted in Stiglitz, op. cit.

Samuelson P.A. (2004), "Where Ricardo and Mill Rebut and Confirm Arguments of Mainstream Economists supporting Globalization", Journal of Economic Perspective; 18, 3, Summer:135-46.

Shafaeddin (2005.a), Is Industrial Policy Relevant in the $21^{\text {st }}$ Century (Kuwait, Arab Planning Institute reprinted by TWN): 9-14.

Shafaeddin, M (2005.b). "Towards an Alternative Perspective on Trade and Industrial Policies", Development and Change, 36.6:1143-1162.

Shafaeddin, M.(2005.c), Trade Policy at the Crossroads; the Recent Experience of Developing Countries, Palgrave, Macmillan. 
Shafaeddin (2006.a), "Beware of NAMA's Slippery Slope to Industrialization", SUNS, 15 June available at http://www2.unine.ch/webdav/site/irene/shared/documents/SUNS15Shafaeddin.pdf

Shafaeddin (2006.b), "Does Trade Openness favour or Hinder Industrialization and development", a paper presented to the technical group meeting of Intergovernmental Group of 24 on International monetary affairs, Geneva, United nations, 16-17 march 2006, available at www.g24.org/msha0306.pdf

Singer, H. W. (1989), "Lessons of Post-War Development Experience: 1945-1988", Discussion Paper, No. 260, Institute of development Studies, Sussex.

South Centre (2007), Comments to the Chairman's Draft NAMA Modalities, Analytical

Note, SC/AN/TDP/MA/7 (Geneva, South Centre).

South -North Development Monitor (SUNS), 16 August 2007.

Subast, T. (2003) "What Does the Hechscher-Ohlin Model Contribute to International Trade Theory"? A Critical assessment", Review of radical political Economics,35,2,148-65

UNCTAD (1985), Trade and development Report, 1984 (United Nations, New York).

UNCTAD (2007), World Investment Report, 2007 (United Nations, New York).

Viner, J. (1953), International Trade and Economic Development (Oxford, Clarendon Press).

Wade, R. (2005), "What Strategies Are Viable for Developing Countries Today? The World Trade Organization and Shrinking of Development Space" in Gallagher K.P(ed). (2005), Putting Development First, the importance of Policy Space in the WTO and IFIs, (London and New York, ZED Books): 80-101, particularly p.89.

R. Wade (2006),'How to Change the WTO and Global Policy on Trade and Investment: Gaining Acceptance of "Open Economy Industrial Policy" by Hoisting Neoliberalism on its Own Petard"; Note for Princeton conference on "Normative and Empirical Evaluation of global Governance", Feb.16-18, Revised 4 March, p.8.

Wade, (2007), "Does trade liberalization promote economic prosperity", in Haas,P. and Hirs, J. (2007), Controversies in Globalization, (Congressional Quarterly Press). 
Williamson, J.(ed.) (1990) “ Latin American Adjustment: How Much Has Happened? (Washington, D.C., Institute of International economics), Chapters 1 and 9What WTO (1998) World Trade Report, 1998 ((Geneva, WTO)

WTO (2006), World Trade Report, 2006 (Geneva, WTO). 